Article

\title{
The Incidence of Skin Cancer in Relation to Climate Change in South Africa
}

\author{
Caradee Y. Wright $1,2, * \mathbb{1}$, Mary Norval ${ }^{3}$, Thandi Kapwata ${ }^{4,5}$, David Jean du Preez ${ }^{2}$, \\ Bianca Wernecke ${ }^{4,5}$, Bianca M. Tod ${ }^{6}$ and Willem I. Visser ${ }^{6}$ \\ 1 Environment and Health Research Unit, South African Medical Research Council, Pretoria 0001, South Africa \\ 2 Department of Geography, Geoinformatics and Meteorology, University of Pretoria, Pretoria 0001, \\ South Africa; dupreez.jd@gmail.com \\ 3 Biomedical Sciences, University of Edinburgh Medical School, Edinburgh EH8 9AG, UK; \\ Mary.Norval@ed.ac.uk \\ 4 Environment and Health Research Unit, South African Medical Research Council, Johannesburg 2028, \\ South Africa; Thandi.Kapwata@mrc.ac.za (T.K.); bianca.wernecke@mrc.ac.za (B.W.) \\ 5 Department of Environmental Health, Faculty of Health Sciences, University of Johannesburg, PO Box 524, \\ Auckland Park 2006, South Africa \\ 6 Division of Dermatology, Department of Medicine, Faculty of Medicine and Health Sciences, Stellenbosch \\ University and Tygerberg Academic Hospital, Cape Town 7505, South Africa; biancatod@gmail.com (B.M.T.); \\ wvisser@sun.ac.za (W.I.V.) \\ * Correspondence: caradee.wright@mrc.ac.za; Tel.: +27-12-339-8543
}

Received: 29 August 2019; Accepted: 2 October 2019; Published: 22 October 2019

check for updates

\begin{abstract}
Climate change is associated with shifts in global weather patterns, especially an increase in ambient temperature, and is deemed a formidable threat to human health. Skin cancer, a non-communicable disease, has been underexplored in relation to a changing climate. Exposure to solar ultraviolet radiation (UVR) is the major environmental risk factor for skin cancer. South Africa is situated in the mid-latitudes and experiences relatively high levels of sun exposure with summertime UV Index values greater than 10. The incidence of skin cancer in the population group with fair skin is considered high, with cost implications relating to diagnosis and treatment. Here, the relationship between skin cancer and several environmental factors likely to be affected by climate change in South Africa are discussed including airborne pollutants, solar UVR, ambient temperature and rainfall. Recommended strategies for personal sun protection, such as shade, clothing, sunglasses and sunscreen, may change as human behaviour adapts to a warming climate. Further research and data are required to assess any future impact of climate change on the incidence of skin cancer in South Africa.
\end{abstract}

Keywords: air pollution; environmental health; rainfall; sun exposure; temperature

\section{Introduction}

Climate change is deemed the greatest threat to public health in the 21st Century [1]. It leads to shifts in weather patterns, increasing ambient temperatures and the occurrence of extreme weather events. These threaten economies, livelihoods and the health and wellbeing of people globally. While many studies have considered climate change in relation to vector- and water-borne diseases in South Africa, little is known about non-communicable diseases such as skin cancer for which the major environmental risk factor is exposure to solar ultraviolet radiation (UVR). Here the geography of South Africa is first described before summarising the epidemiology of skin cancer in this country. An attempt is made to explore the relationship between skin cancer and several environmental factors 
likely to be affected by climate change. These findings are then used to suggest recommendations for reducing the risk of skin cancer and encouraging sun protection for South Africans.

\section{South African Geography and Population}

Situated at the southern tip of Africa, South Africa spans from approximately $22^{\circ}$ to $34^{\circ} \mathrm{S}$ and comprises nine Provinces (Figure 1). The country's topography includes coastal plains at sea level and a central plateau, known as the Highveld, at an average altitude of $1200 \mathrm{~m}$. A stationary high-pressure cell over the Highveld and interior of the country results in relatively cloudless skies, which together with the altitude, contributes to high solar UVR levels. Erythemally-weighted irradiances from the Ozone Monitoring Instrument (OMI) are calculated at approximately solar noon when the satellite passes over. The erythemally-weighted irradiances are calculated between $290-400 \mathrm{~nm}$ and are corrected for local terrain height [2,3]. Using the daily (2004-2018) erythemally-weighted irradiances [4], the mean ultraviolet index (UVI) [5] values for winter and summer months were calculated for South Africa (Figure 2). During summer, most of the interior of the country experiences levels above 10 UVI with the highest observed over the Northern Cape Province. In winter, the northern parts of the country have the highest levels of about $5 \mathrm{UVI}$, while they are lower in the southern regions.

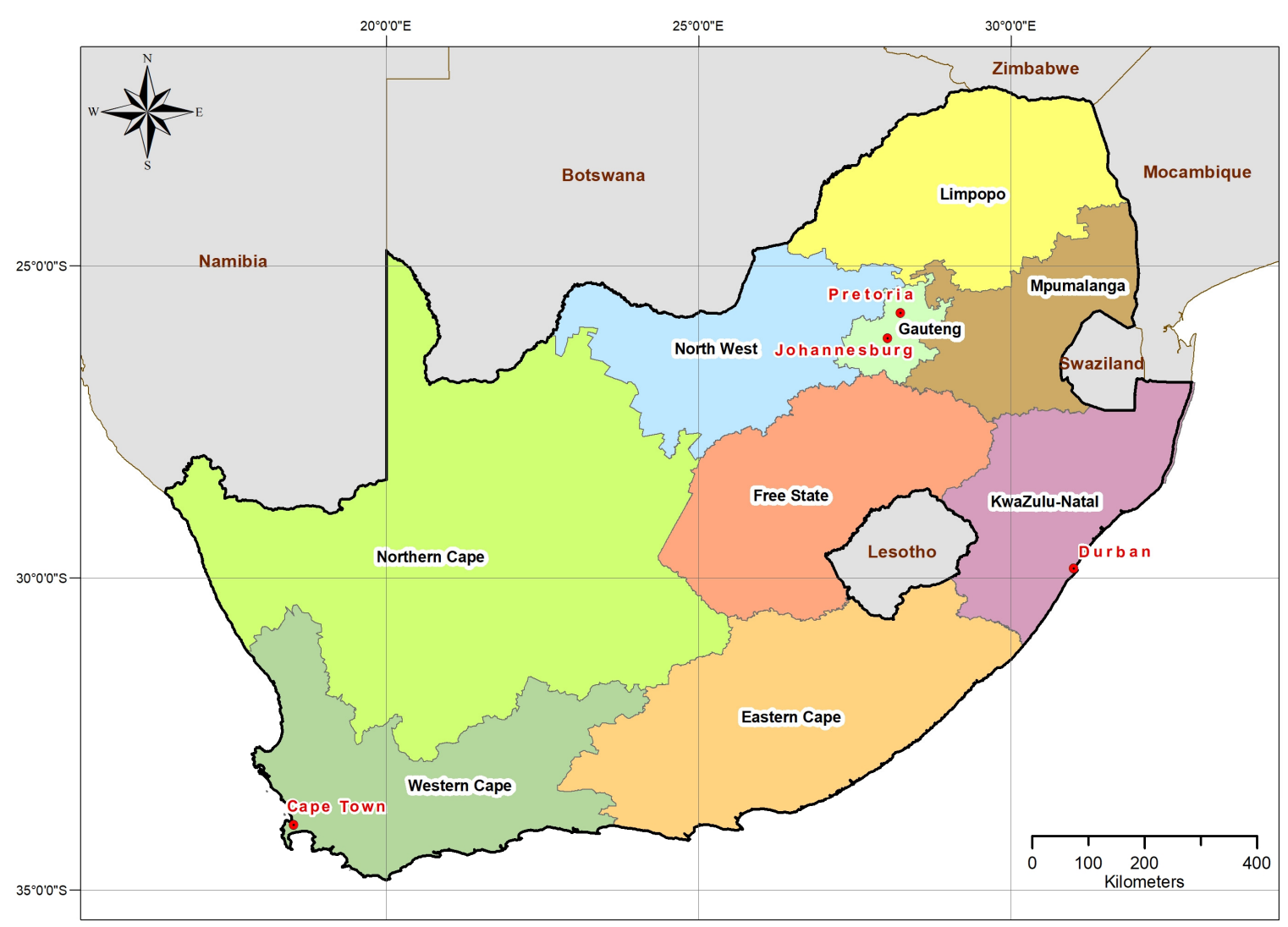

Figure 1. The Provinces and four largest cities of South Africa (Map produced by T Kapwata).

South Africa's multi-ethnic population is officially grouped into Black African, Mixed Ancestry (mixed European (white) and African (black) or Asian ancestry, with skin colour ranging from pale to dark brown), Asian/Indian and White. According to the 2018 mid-year population estimates $81 \%$ were Black African, 9\% Mixed Ancestry, 8\% White, and 2\% Indian/Asian [6]. The mid-year population in 2018 was 57.7 million [6]. 


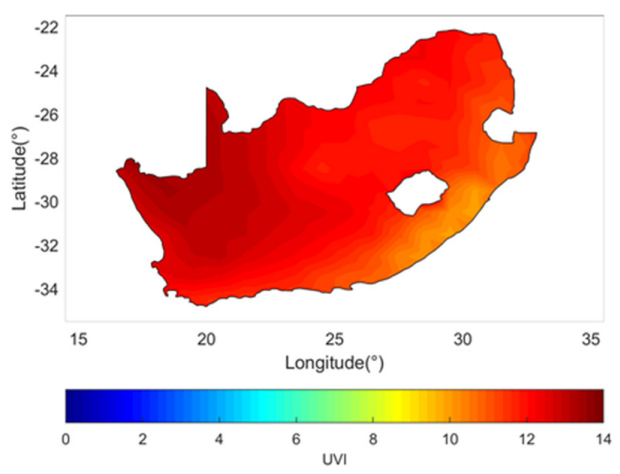

(a)

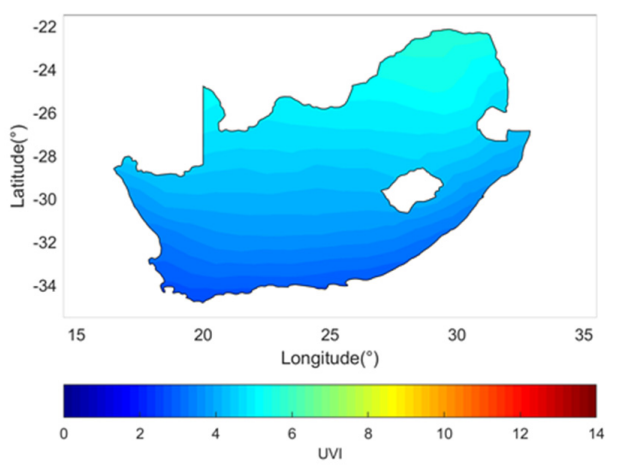

(b)

Figure 2. Mean (a) summer and (b) winter UV Index values over South Africa (maps drawn by D J du Preez).

\section{Current Incidence of Skin Cancer and Mortality Data}

Skin cancer can be broadly divided into two types: cutaneous melanoma (CM) and keratinocyte carcinoma (KC). KCs are the most common malignancies worldwide [7] with basal cell carcinoma (BCC) being the most frequent followed by squamous cell carcinoma (SCC). All skin cancers have shown an increase in incidence worldwide over the past decades [7,8], although many of the cancer registries exclude $\mathrm{KCs}$ due to their low mortality rates and, in those that do include them, under-reporting is common.

The incidence of skin cancer in South Africa is monitored by the National Cancer Registry (NCR). This was established in 1986 as a pathology-based cancer reporting system and reporting skin cancers to the NCR is mandatory. Table 1 presents skin cancer statistics from 2014. It is evident from these figures that $\mathrm{CM}$ and $\mathrm{KC}$ are found in White individuals predominantly but can also occur in people with deeply pigmented skin although at a greatly reduced rate.

An increase in the incidence of $\mathrm{CM}$ and $\mathrm{KC}$ in White and Black African men and women was demonstrated when the data from 2000-2004 [9] were compared with the 2014 data. The age-related mortality rates for the period 1997-2014 due to CM in South Africa showed an increasing trend of $11 \%$ per year in men between 2000 and 2005, rising from 2 to 3 per 100,000 after which the rate plateaued [10]. In women, there was a smaller increase of $2 \%$ per year from 1997-2014, rising from 0.9 to 1.3 per 100,000 . Deaths as a result of CM occur in the whole range of skin phototypes found in the South African population groups [10]. No statistics for deaths due to SCC and BCC are available.

Table 1. Skin cancer statistics for South Africa for the year 2014 from NCR [11].

\begin{tabular}{|c|c|c|}
\hline \multicolumn{2}{|c|}{ Age Standardised Incidence } & Rate per 100,000 \\
\hline \multirow{3}{*}{ Cutaneous Melanoma } & All & 2.7 \\
\hline & Black African & 0.5 \\
\hline & White & 23.2 \\
\hline \multirow{2}{*}{ Basal Cell Carcinoma } & Females & 28.6 \\
\hline & Males & 55.6 \\
\hline \multirow{4}{*}{ Basal Cell Carcinoma } & White Females & 138.0 \\
\hline & White Males & 223.2 \\
\hline & Black African Females & 2.2 \\
\hline & Black African Males & 3.5 \\
\hline \multirow{2}{*}{ Cutaneous Squamous Cell Carcinoma } & Females & 10.6 \\
\hline & Males & 25.6 \\
\hline \multirow{4}{*}{ Cutaneous Squamous Cell Carcinoma } & White Females & 38.8 \\
\hline & White Males & 84.5 \\
\hline & Black African Females & 2.0 \\
\hline & Black African Males & 3.5 \\
\hline
\end{tabular}




\section{Costs Due to Skin Cancer in South Africa}

A study modelling the costs of diagnosing and treating skin cancer in South Africa estimated that ZAR 92.5 million (US\$15.7 million) was spent in 2015 on treating CMs, SCCs and BCCs. On average, each confirmed case of CM cost ZAR 4197 (US\$712), while each confirmed KC cost ZAR 2767 (US\$470) [12]. Only direct medical figures were included in this analysis while peripheral figures associated with a diagnosis of skin cancer were not assessed, such as loss of income, administration of disability grants, insurance claims, transport and accommodation of patients from outside of major centres.

As there is a high incidence of KCs in South Africa, the expenditure on diagnosis and treatment is large even though these tumours have a low rate of major morbidity and mortality. It is important to note that thicker CM are associated with a significant cost escalation (ZAR 2931 (US\$497) for lesions $<1 \mathrm{~mm}$ thick, and ZAR 7149 (US\$1213) for lesions $>1 \mathrm{~mm}$ thick), providing an economic argument for screening at risk populations [12]. Most CMs in SA are diagnosed in the private sector [13]. Melanoma is considered by one of the largest private medical insurers to be amongst the top ten cancers by cost within the scheme, with an average cost per member of ZAR 60,926 (as at Jan-Dec 2017) [14]. A recent study predicted increases in KCs for the world population in the foreseeable future [15]. Given the associated costs, any increase in the incidence of skin cancers in South Africa due to climate change is likely to present a significant financial burden for both the private and public sectors.

\section{Air Pollution and Skin Cancer}

Poor air quality, and the resulting human exposure to air pollution, has been defined as the world's single largest environmental health risk [16]. Poor air quality arises from various activities including veld fires, wind-blown dust, coal-fired power stations and vehicle emissions.

Recently, evidence suggests that, over and above the recognised negative effects that air pollution has on respiratory and cardiovascular health, it is also detrimental to skin integrity $[17,18]$ due to direct exposure to airborne pollutants such as particulate matter (PM), volatile organic compounds (VOCs), ozone, nitrogen dioxide and sulphur dioxide [18].

PM and polycyclic aromatic hydrocarbons can cause skin cancer in animal models [19]. The pollutants may penetrate the skin through the exposed site or may be inhaled, thus becoming systemic through the respiratory tract. Four potential mechanisms that account for the harmful effects of air pollution on skin have been identified: generation of free radicals, induction of inflammatory cascade and disruption of skin barrier, activation of the aryl hydrocarbon receptor, and alterations to skin microflora $[19,20]$. The presence of free radicals, in particular, increases the risk of skin cancer through mechanisms such as the promotion of oxidative stress and a proinflammatory environment in the skin and DNA damage [21,22]. In addition, ambient ozone's unstable characteristics cause it to be highly reactive, directly targeting the skin's surface, and oxidizing with molecules in the outermost layer of the epidermis (stratum corneum). This causes skin barrier alterations and dysfunction as well as oxidative stress and inflammation [21,22].

Air quality in South Africa, particularly in industrial and defined airshed priority areas (regional areas in South Africa where air pollution standards are being exceeded and which have been given priority by the government for air quality management) [23] is exceptionally poor, with national ambient air quality standards regularly being exceeded in the ambient, but also the indoor environment [24-26]. Given the reliance of the country on the combustion of fossil fuels for the generation of electricity, and the growing demand for power, the air pollution burden, which is in large part determined by industrial activities, is predicted to represent a serious human health risk well into the country's future [27]. Increased migration into urban centres is also predicted to increase the incidence of the "indoor air pollution" phenomenon seen in many unelectrified low-income areas around South Africa's big cities. Here, reliance on dirty fuels for heating and cooking activities is high, creating unsafe air to breathe inside people's homes [28]. Exposure to particulate matter concentrations represents a real health burden in many parts of the country. 
The increasing air pollution burden (for example, desertification leading to increases in wind-blown dust, and warmer, drier conditions leading to increased fires) together with the possible consequent cutaneous changes induced by airborne pollutants in the context of climate change are likely to contribute to an increase in the incidence of skin cancer.

\section{Solar Ultraviolet Radiation Exposure, Temperature and Skin Cancer}

Exposure to solar UVR is recognised as the major environmental risk factor for skin cancer [29]. Although the patterns of solar UVR exposure that increase cutaneous tumorigenesis remain unclear, it is likely that they differ between the three main types of skin cancer. For CM, a high dose of UVR at any time during life increases the risk, but particularly if it occurs during childhood and is associated with the development of naevi [30]. For SCC, which develops almost entirely on body sites that are frequently exposed to the sun, cumulative UVR exposure is key. For BCC, the interaction with UVR is more complex as many of these tumours are found on the trunk, a body site, which is not commonly sun exposed. This suggests that intermittent sun exposure, as could occur during recreational activities, may be important, in addition to early life and cumulative irradiation [31]. As indicated in the Introduction, there is the potential for excess personal sun exposure in South Africa due to its subtropical location, climate and topography. Table 2 shows the UVI and average day and night-time temperatures in the summer and winter in the four most populous cities.

Table 2. Characteristics of the four major cities in South Africa [32-34].

\begin{tabular}{cccccc}
\hline Characteristic & & Cape Town & Durban & $\begin{array}{c}\text { Johannesburg } \\
\text { Including Soweto }\end{array}$ & Pretoria \\
\hline 2018 population size estimate (millions) & 3.4 & 3.1 & 3.7 & 1.6 \\
Latitude $\left({ }^{\circ} \mathrm{S}\right)$ & & 34 & 29 & 26 & 26 \\
Altitude $(\mathrm{m})$ & $0-300$ & $0-21$ & 1750 & 1340 \\
\hline \multirow{2}{*}{ Ultraviolet Index (average values at noon) } & Summer & $9-10$ & $10-11$ & $11+$ & $11+$ \\
\cline { 2 - 5 } & Winter & $2-3$ & $3-4$ & $4-6$ & $4-6$ \\
\hline \multirow{2}{*}{ Average day-time temperatures $\left({ }^{\circ} \mathrm{C}\right)$} & Summer & 26 & 29 & 26 & 30 \\
\cline { 2 - 5 } & Winter & 19 & 24 & 19 & 21 \\
\hline \multirow{2}{*}{ Average night-time temperatures $\left({ }^{\circ} \mathrm{C}\right)$} & Summer & 15 & 21 & 15 & 18 \\
\cline { 2 - 5 } & Winter & 8 & 11 & 4 & 5 \\
\hline
\end{tabular}

The UV portion of the solar spectrum comprises about $5 \%$ of terrestrial sunlight. It is divided arbitrarily into three spectral regions defined as UVA (315-400 nm), UVB (280-315 nm) and UVC (100-280 nm), although alternative wavebands of UVA (320-400 nm), UVB (290-320 nm) and UVC $(200-290 \mathrm{~nm})$ are also used. The solar UV rays are modified as they pass through the atmosphere. Absorption by ozone and scattering by molecules such as $\mathrm{N}_{2}$ and $\mathrm{O}_{2}$ take place in the stratosphere, while absorption by pollutants and scattering by particulates and clouds occur in the troposphere. These interactions result in terrestrial UVR containing approximately $94 \%$ UVA and $6 \%$ UVB, with no UVC except at high altitude. The UVB component is more effective biologically than UVA at inducing changes in the skin which can lead to the induction of tumours and thus its relative concentration in sunlight is critical.

More than 40 years ago, it was discovered that the ozone layer in the stratosphere was thinning with holes appearing, mainly over the Poles, especially in Antarctica. This change resulted in a rise in the UVB component in terrestrial sunlight, with implications for increasing the risk of skin cancer. For example, if unchecked, it has been calculated that the UVI in the tropics would have risen to peaks greater than 35 and an increase in UV of 1\% would correspond to an increase in the global incidence of skin cancer of 2-3\% [35]. The Montreal Protocol, implemented in 1987, together with its amendments and adjustments, sought to reduce the concentration of ozone-depleting substances world-wide [36]. The success of this strategy is shown by the global $\left(60^{\circ} \mathrm{N}\right.$ to $\left.60^{\circ} \mathrm{S}\right)$ column ozone no longer declining, with small increases of $0.3-1.2 \%$ per decade since 1997 reported [37] and signs of the 
Antarctic ozone hole recovery [38]. The gradual repair of the ozone layer will probably not be complete for another 50 years or so, although it may be delayed by climate changes that alter atmospheric circulation patterns, cloud cover and stratospheric temperatures [35].

Regarding the area of the world in which South Africa lies, close to zero changes in total ozone since the mid-1990s have been observed, with the average projected changes in UVI being $0-2 \%$ [39]. Thus, if this trend continues, there should not be any significant increase in the incidence of skin cancer due to ozone depletion alone in South Africa.

One important factor, which may alter the effect of solar UVR on the incidence of skin cancer is ambient temperature. The increase in temperatures in the last century has been estimated as $0.6^{\circ} \mathrm{C}$ world-wide and is projected to be between $0.9-3.5^{\circ} \mathrm{C}$ for the present century, and between $0.75-6.3^{\circ} \mathrm{C}$ by 2200 [15]. As early as 1943 it was shown that mice exposed to chronic UVR developed 3\% more skin tumours per ${ }^{\circ} \mathrm{C}$ rise in temperature above $23^{\circ} \mathrm{C}$ [40]. This led van der Leun and de Gruijl [37] to suggest that global warming may be more relevant than ozone depletion to increasing skin cancer incidence in future years. By calculating the incidence of $\mathrm{KC}$ together with the ambient UV dose and average daily maximum temperature in the summer in ten regions of the USA, van der Leun and de Gruijl [37] indeed found that the incidence of SCC was $5.5 \%$ higher per ${ }^{\circ} \mathrm{C}$ and $2.9 \%$ higher per ${ }^{\circ} \mathrm{C}$ for BCC. They concluded that there was an increase in the effective UV dose by approximately $2 \%$ per ${ }^{\circ} \mathrm{C}$. Further studies have indicated that a $2{ }^{\circ} \mathrm{C}$ increase in ambient temperature might increase the number of skin cancers by $10 \%$ annually [41]. The reasons for the higher temperature leading to a higher incidence of skin tumours is not clear but there is known to be a reduction in heat-mediated apoptosis induced by UVB in keratinocytes and in p53-mediated cell cycle arrest, leading to increased survival of DNA-damaged cells [42].

Currently warming trends (increasing maximum and minimum temperatures) are found in Africa with the ambient temperatures projected to rise faster than the global average increases [43]. Indeed, an increase of $4-6^{\circ} \mathrm{C}$ is estimated for Southern Africa by 2071-2100. It is recognised that above a threshold of $27^{\circ} \mathrm{C}$, heat starts to impact adversely on health. Above $38^{\circ} \mathrm{C}$ heat exhaustion can occur, and, above $40.6^{\circ} \mathrm{C}$, heat stroke is possible. Projections for Johannesburg indicate that, while there was an average of 35 days per year in $1961-1990$ when the temperature exceeded $27^{\circ} \mathrm{C}$, this will rise to 70 days in 2100-2040 and to 101-120 days in 2041-2070 [44]. What impacts this trend will have on the incidence of skin cancer are unknown. On the one hand, it could lead to a significant increase in the incidence of KCs and CMs due to the cutaneous interaction between UVB and temperature, more time being spent outdoors, wearing less protective clothing and possibly less cloud cover. Alternatively, adaptation to living at constant high temperatures is possible, although this might not happen quickly enough to halt the change in skin cancer risk. It should be noted that a protective effect of mild heat preconditioning $\left(42{ }^{\circ} \mathrm{C}\right)$ has been demonstrated in mice by the stimulation of HSP70 chaperones, thus inhibiting cutaneous inflammation and wrinkle formation [45]. Whether such an effect due to increased ambient temperatures occurs in humans and if it might reduce the risk of skin cancer is unknown currently.

In addition, when the ambient temperature is above, say $30^{\circ} \mathrm{C}$, human behaviour is likely to alter with more time spent indoors, shade being sought and perhaps more effective building insulation with air conditioning for those who can afford it. For example, in Austria, the frequency of people being outdoors decreased at temperatures higher than $30^{\circ} \mathrm{C}$ [46]. Another behavioural factor relates to trends in fashion. For the past few decades, it is widely believed by those with fair skin that having a tan is healthy, and relates to affluence and beauty; in contrast, those with pigmented skin frequently seek to avoid the sun to prevent skin darkening and ageing. Whether such societal behaviour will persist in the coming decades is unknown.

Whatever the circumstances might be, a time-lapse of approximately 60 years has been suggested between changes in ozone and ambient temperatures and any impact on the incidence of skin cancer due to the long lag period associated with cutaneous carcinogenesis [47]. 


\section{Rainfall, Cloud Cover and Skin Cancer}

Africa is particularly vulnerable to climate-induced impacts on rainfall as it is not only reliant on rain-fed agriculture but also through changes in cloud cover, which alter the quantity of solar UVR reaching the surface of the Earth [48-50]. Aerosols have a direct effect by scattering and absorbing incoming UVR and an indirect effect by acting as condensation nuclei for the formation of clouds [51]. Clouds generally reduce UV intensity although not so significantly as infrared intensity. However, it should be noted that patchy clouds can lead to an increase in ambient UVR by reflection from the clouds' edges, and that thin, wispy clouds can redirect UV rays, thereby also increasing ambient UVR.

The rainfall regions of South Africa vary greatly due to the displacement of the Hadley cell as a result of the changes in solar insolation. The Hadley cell is a thermally-driven circulation and consists of rising air at the equator which is then transported to latitude $30^{\circ} \mathrm{S}$ and descends [52]. During summer, moisture from the Southwest Indian Ocean and Agulhas current is transported to South Africa with the easterly winds. During winter, dry air is transported from the South Atlantic Ocean through the westerly winds. The El Niño-Southern Oscillation (ENSO) modulates the annual precipitation variability [53].

Over southern Africa, there has been no consistent trend in annual rainfall values although changes in the onset of seasonal rainfall, dry spell frequencies and rainfall intensities have occurred [54]. The rainfall predictions from climate models offer little consensus although a small decline in annual rainfall is possible with increased seasonal variability [53]. Any impact of these rainfall variations on cloud cover has not been assessed.

The potential impact of changes in rainfall on skin cancer includes the length of time spent outdoors. In places where the rainfall decreases, or where drought persists, people may spend more time than usual outdoors either for recreational purposes or, in the case of rural, low socio-economic areas, to collect water. Conversely, should rainfall increase with an increase in cloud cover, solar UVR exposure may decrease, depending on the nature of the cloud, thereby reducing skin cancer risk.

\section{Adaptation Strategies}

Sun protection can reduce the risk of skin cancer and mitigate the harmful effects of excess solar UVR exposure. The World Health Organization advises five key messages for sun protection against excess sun exposure [55]. First, to limit the time spent in the midday sun between 10 and $16 \mathrm{~h}$. Secondly, to take note of the UV Index, an important resource that indicates the severity of solar UVR during the course of the day. Then, individuals are advised to use shade wisely and to remember the shadow rule: "Watch your shadow: short shadow, seek shade!". The third and fourth messages are to wear protective clothing, such as a wide brim hat, sunglasses and tightly woven loose-fitting clothes, and to use sunscreen. The sunscreen should be broad-spectrum, have a Sun Protection Factor of at least $15+$ and be re-applied every two hours, or after swimming, working, playing or exercising outdoors. Sun protection is advocated in high exposure settings such as at school playgrounds, sports facilities and the beach. Several of these messages prompting behavioural change regarding sun protection may be impacted upon by climate change, particularly an increase in ambient temperature. Studies have reported that people find it uncomfortable to wear clothing and sunscreen in hot weather [56]. Shade will be essential in hot weather. The shade should be effective at preventing exposure to both direct and diffuse solar UVR [57].

Agriculture is an important economic activity in South Africa and the health risks of farm workers due to chronic exposure to high solar UVR merit special consideration. Similarly, outdoor workers in construction and roadwork also require adequate protection from excess solar UVR exposure and heat [58]. Attention needs to be given to holding outdoor activities at times which avoid the sun at peak intensity; there should be sun protection programmes that target children and adolescents, and schools should develop sun protection policies, in addition to trying to ameliorate the deleterious effects of high ambient temperatures on human health. 


\section{Conclusions}

An increase in the incidence of CM and KC in the population groups of South Africa has occurred in recent years, with cost implications relating to diagnosis and treatment. There are several ways in which climate change could affect the current incidence rates. These relate to shifts in meteorological variables, particularly air pollution, temperature, rainfall and cloud cover, all of which influence solar UVR levels at the Earth's surface. Although more data are required, a rising air pollution burden is likely to lead to cutaneous damage, thus increasing the risk of skin cancer. Higher ambient temperatures have been associated with an increasing frequency of skin cancer due to changes in the tumourigenesis process and to more time spent outdoors.

National collection of accurate statistics regarding the trends in the incidence of skin cancer and mortality data are urgently required, including population group, age, sex and stage at diagnosis to consider skin cancer-related associated risk factors associated with climate change. It is also important to relate these to any alterations in the ozone layer, ambient temperature, air-borne pollution and rainfall together with any changes in personal sun exposure. This information will help to craft appropriate public health messages regarding reducing the risk of skin cancer in a changing climate. It will also help to raise awareness of potential health risks and to tailor sun protection messaging to the different population groups in South Africa.

Author Contributions: Conceptualization, M.N. and C.Y.W. Writing—original draft preparation: All authors. Writing-review and editing: All Authors.

Funding: C.Y.W., B.W. and T.K. receive research funding support from the South African Medical Research Council and the National Research Foundation. D.J.d.P. receives funding from the National Research Foundation. M.N., B.M.T. and W.I.V. have no funding sources to declare.

Acknowledgments: We acknowledge the National Cancer Registry of South Africa for provision of the data.

Conflicts of Interest: The authors declare they have no actual or potential conflicting interests.

\section{References}

1. Watts, N.; Amann, M.; Arnell, N.; Ayeb-Karlsson, S.; Beleson, K.; Berry, K.; Bouley, T.; Boykoff, M.; Byass, P.; Cai, W.; et al. The 2018 report of the Lancet Countdown on health and climate change: Shaping the health of nations for centuries to come. Lancet 2018, 392, 2479-2514. [CrossRef]

2. Stammes, P.; Noordhoek, R. OMI Algorithm Theoretical Basis Document Volume III: Clouds, Aerosols, and Surface UV Irradiance; Technology Report ATBD-OMI-03; KNMI: De Bilt, The Netherlands, 2002.

3. OMI Team. Ozone Monitoring Instrument (OMI) Data user's Guide; NASA: Washington DC, USA, 2012.

4. Hovila, J.; Arola, A.; Tamminen, J. OMI/Aura Surface UVB Irradiance and Erythemal Dose Daily L3 Global Gridded 1.0 degree x 1.0 degree V3, NASA Goddard Space Flight Center, Goddard Earth Sciences Data and Information Services Center (GES DISC). Available online: 10.5067/Aura/OMI/DATA3009 (accessed on 14 March 2019).

5. World Health Organization. UV Index. Available online: https://www.who.int/uv/intersunprogramme/ activities/uv_index/en/ (accessed on 30 September 2019).

6. Statistics SA. Mortality and Causes of Death in South Africa, 2016-Findings from Death Notification. Statistical release P0309.3. Available online: http://www.statssa.gov.za/publications/P03093/P030932016.pdf (accessed on 14 March 2019).

7. Cameron, M.C.; Lee, E.; Hibler, B.P.; Barker, C.B.; Mori, S.; Cordova, M.; Nehal, K.S.; Rossi, A.M. Basal Cell Carcinoma: Epidemiology; Pathophysiology; Clinical and Histological Subtypes; and Disease Associations. J. Am. Acad Dermatol. 2018, 80, 303-317. [CrossRef]

8. Lucas, R.M.; Tazar, S.; Young, A.R.; Norval, M.; de Gruijl, F.R.; Rhodes, L.E.; Sinclair, C.A.; Neale, R.E. Human health in relation to exposure to solar ultraviolet radiation under changing stratospheric ozone and climate. Photochem. Photobiol. Sci. 2019, 18, 641-680. [CrossRef] [PubMed]

9. Norval, M.; Kellett, P.; Wright, C.Y. The incidence and body site of skin cancers in the population groups of South Africa. Photodermatol. Photoimmunol. Photomed. 2014, 30, 262-265. [CrossRef] [PubMed] 
10. Wright, C.Y.; Kapwata, T.; Singh, E.; Green, A.; Baade, P.; Kellett, P.; Norval, M. Trends in melanoma mortality in population groups of South Africa. Dermatology 2019, 235, 396-399. [CrossRef] [PubMed]

11. National Cancer Registry (of SA). Cancer in SA: 2014 Full Report. Available online: http://www.nicd.ac.za/ wp-content/uploads/2017/03/2014-NCR-tables-1.pdf (accessed on 22 March 2019).

12. Gordon, L.G.; Elliott, T.M.; Wright, C.Y.; Deghaye, N.; Visser, W. Modelling the healthcare costs of skin cancer in South Africa. BMC Health Serv. Res. 2016, 16, 113. [CrossRef]

13. Tod, B.; Kellett, P.; Singh, E.; Visser, W.; Lombard, C.; Wright, C.Y. The incidence of melanoma in South Africa: An exploratory analysis of National Cancer Registry data from 2005 to 2013 with a specific focus on melanoma in Black Africans. S. Afr. Med. J. 2019, 109, 246-253. [CrossRef]

14. Discovery Health. Healthcare Claims Tracker: A Focus on Oncology Claims. Available online: https://www.discovery.co.za/assets/discoverycoza/medical-aid/find-a-document/guides/healthcare-claimstracker-oncology-claims.pdf (accessed on 18 March 2019).

15. Piacentini, R.D.; Della Ceca, L.S.; Ipina, A. Climate change and its relationship with non-melanoma skin cancers. Photochem. Photobiol. Sci. 2018, 17, 1913-1917. [CrossRef]

16. Kim, K.E.; Cho, D.; Park, H.J. Air pollution and skin diseases: Adverse effects of airborne particulate matter on various skin diseases. Life Sci. 2016, 152, 126-134. [CrossRef]

17. Krutmann, J.; Liu, W.; Li, L.; Pan, X.; Crawford, M.; Sore, G. Pollution and skin: From epidemiological and mechanistic studies to clinical implications. J. Dermatol. Sci. 2014, 76, 163-168. [CrossRef]

18. Mancebo, S.E.; Wand, S.Q. Recognizing the impact of ambient air pollution on skin health. J. Eur. Acad. Dermatol. Venereol. 2015, 29, 2326-2332. [CrossRef] [PubMed]

19. Zegarska, B.; Pietkun, K.; Giemza-Kucharska, P.; Zegarski, T.; Nowacki, M.S.; Romanska-Gocka, K. Changes in Langerhans cells during skin ageing. Postepy. Dermatol. Alergol. 2017, 34, 260-267. [CrossRef] [PubMed]

20. Burke, K.E.; Wei, H. Synergistic damage by UVA radiation and pollutants. Toxicol. Indus. Health 2009, 25, 219-224. [CrossRef] [PubMed]

21. Poljsak, B.; Glavan, U.; Dahmane, R. Skin Cancer, Free radicals and antioxidants. Int. J. Res. Prev. 2011, 4, 193-217.

22. Parrado, C.; Mercado-Saenz, S.; Perez-Davo, A.; Gilberte, Y.; Gonzalez, S.; Juarranz, A. Environmental Stressors on Skin Aging. Mechanistic Insights. Front. Pharmacol. 2019, 10, 1-17. [CrossRef]

23. Republic of South Africa. Government Gazette National Environment Management: Air Quality Act. 2005; Volume 476, p. 27318. Available online: https://www.environment.gov.za/sites/default/files/legislations/ nema_amendment_act39.pdf (accessed on 27 August 2019).

24. Josipovic, M.; Annegarn, H.J.; Keen, M.A.; Pienaar, J.J.; Piketh, S.J. Concentrations, distributions and critical level exceedance assessment of $\mathrm{SO}_{2}, \mathrm{NO}_{2}$ and $\mathrm{O}_{3}$ in South Africa. Environ. Monit. Assess. 2010, 171, 181-196. [CrossRef]

25. Garland, R.M.; Naidoo, M.; Sibiya, B.; Oosthuizen, M.A. Air quality indicators from the Environmental Performance Index: Potential use and limitations in South Africa. Clean Air J. 2017, 27, 1-9. Available online: https://www.cleanairjournal.org.za/journals/volume27_no1_2017/volume27_no1_2017_p33.php (accessed on 27 August 2019). [CrossRef]

26. Morakinyo, O.M.; Adebowale, A.S.; Mokgobu, M.I.; Mukhola, M.S. Health risk of inhalation exposure to sub-10 $\mu \mathrm{m}$ particulate matter and gaseous pollutants in an urban-industrial area in South Africa: An ecological study. BMJ 2017, 7, 1-9. [CrossRef]

27. Pollet, B.G.; Staffell, I.; Adamson, K. Current energy landscape in the Republic of South Africa. Int. J. Hydrogen Energ. 2015, 40, 16685-16701. [CrossRef]

28. Arndt, C.; Davies, R.; Thurlow, J. Urbanisation, Structural Transformation and Rural-Urban Linkages in South Africa (2018). Available online: https://csp.treasury.gov.za/Resource\%20_Centre/Conferences/ Documents/Urbanization\%20Review\%20Papers/Paper\%203\%20-\%20RSA\%20Urbanization.pdf (accessed on 27 August 2019).

29. Narayanan, D.L.; Saladi, R.N.; Fox, J.L. Ultraviolet radiation and skin cancer. Int. J. Dermatol. 2010, 49, 978-986. [CrossRef]

30. Armstrong, B.K.; Cust, A.E. Sun exposure and skin cancer, and the puzzle of cutaneous melanoma: A perspective on Fears et al. Mathematical models of age and ultraviolet effects on the incidence of skin cancer among whites in the United States. Cancer Epidemiol. 2011, 48, 147-156. [CrossRef] [PubMed] 
31. Kricker, A.; Weber, M.; Sitas, F.; Banks, E.; Rahman, B.; Goumas, C.; Kabir, A.; Hodgkinson, V.S.; van Lemenade, C.H.; Waterboer, T.; et al. Early life UV and risk of basal and squamous cell carcinoma in New South Wales, Australia. Photochem. Photobiol. 2017, 93, 1483-1491. [CrossRef] [PubMed]

32. Weather2travel. Available online: www.weather2travel.com (accessed on 27 August 2019).

33. Holiday-Weather. Available online: www.holiday-weather.com (accessed on 27 August 2019).

34. World Population Review. Available online: http://worldpopulationreview.com/countries/south-africapopulation (accessed on 27 August 2019).

35. Newman, P.A.; McKenzie, R. UV impacts avoided by the Montreal Protocol. Photochem. Photobiol. Sci. 2011, 10, 1152-1160. [CrossRef] [PubMed]

36. Bais, A.F.; Bernhard, G.; McKenzie, R.L.; Aucamp, P.J.; Young, P.J.; Ilyes, M.; Jockel, P.; Deushi, M. Ozone-climate interactions and effects on solar ultraviolet radiation. Photochem. Photobiol. Sci. 2019, 18, 602-640. [CrossRef]

37. van der Leun, J.C.; de Gruijl, F.R. Climate change and skin cancer. Photochem. Photobiol. Sci. 2002, 1, 324-326. [CrossRef]

38. Kuttippurath, J.; Nair, P.J. The signs of Antarctic ozone hole recovery. Sci. Rep. 2017, 7, 585. [CrossRef]

39. Bain, J.A.; Rusch, H.P.; Kline, B.E. The effect of temperature upon ultraviolet carcinogenesis with wavelengths 2800-3400 Å. Cancer Res. 1943, 3, 610-612. Available online: https://cancerres.aacrjournals.org/content/3/9/ 610.short (accessed on 3 October 2019).

40. van der Leun, J.C.; Piacentini, R.D.; de Gruijl, F.R. Climate change and human skin cancer. Photochem. Photobiol. Sci. 2008, 7, 730-733. [CrossRef]

41. Kaffenberger, B.H.; Shetlar, D.; Norton, S.A.; Rosenbach, M. The effect of climate change on skin disease in North America. J. Am. Acad. Dermatol. 2017, 76, 140-147. [CrossRef]

42. Calapre, L.; Gray, E.S.; Kurdykowski, S.; David, A.; Hart, P.; Descargues, P.; Ziman, M. Heat-mediated reduction of apoptosis in UVB-damaged keratinocytes in vitro and in human skin ex vivo. BMC Dermatol. 2016, 16, 6. [CrossRef]

43. Kapwata, T.; Gebreslasie, M.T.; Mathee, A.; Wright, C.Y. Current and potential future seasonal trends on indoor dwelling temperature and likely health risks in rural Southern Africa. Int. J. Environ. Res. Public Health 2018, 15, 952. [CrossRef] [PubMed]

44. Garland, R.M.; Matooane, M.; Engelbrecht, F.A.; Bopape, M.-J.M.; Landman, W.A.; Naidoo, M.; van der Merwe, J.; Wright, C.Y. Regional projections of extreme apparent temperature days in Africa and the related potential risk to human health. Int. J. Environ. Res. Public Health 2015, 12, 12577-12604. [CrossRef] [PubMed]

45. Matsuda, M.; Hoshino, T.; Yamakawa, N.; Tahara, K.; Adachi, H.; Sobue, G.; Maji, D.; Ihn, H.; Mizushima, T. Suppression of UV-induced wrinkle formation by induction of HSP70 expression in mice. J. Invest. Derm. 2013, 135, 919. [CrossRef] [PubMed]

46. Schmalwieser, A.W.; Schmalwieser, V.T.; Schmalwieser, S.S. Influence of air temperature on the UV exposure of different body sites due to clothing of young women during daily errands. Photochem. Photobiol. 2019, 95, 1068-1075. [CrossRef]

47. Slaper, H.; Velders, G.M.; Daniel, J.S.; de Gruijl, F.R.; van der Leun, J.C. Estimates of ozone depletion and skin cancer incidence to examine the Vienna Convention achievements. Nature 1996, 384, 256-258. [CrossRef]

48. Diffey, B.L. Climate change, ozone depletion and the impact on ultraviolet exposure of human skin. Phys. Med. Biol. 2003, 49, R1-R11. [CrossRef]

49. Bharath, A.K.; Turner, R.J. Impact of climate change on skin. J. R. Soc. Med. 2009, 102, 215-218. [CrossRef]

50. Cook, K.H.; Vizy, E.K. Impact of climate change on mid-twenty-first century growing seasons in Africa. Clim. Dynam. 2012, 39, 2937-2955. [CrossRef]

51. Lohmann, U.; Feichter, J. Global indirect aerosol effects: A review. Atmos. Chem. Phys. 2005, 5, 715-737. [CrossRef]

52. American Meteorological Society. Glossary of Meteorology. Available online: http://glossary.ametsoc.org/ wiki/Solar_zenith_angle (accessed on 26 February 2019).

53. Jury, M.R. Climate trends in southern Africa. S. Afr. J. Sci. 2012, 109, 1-11. [CrossRef]

54. Ruppel, I.O.C.; Abdrado, M.A.; Essel, A.; Lennard, C.; Padghamp, J.; Urqhaurt, P. Climate Change 2014: Impacts, Adaptation, and Vulnerability. Part B: Regional Aspects. Contribution of Working Group II to the Fifth Assessment Report of the Intergovernmental Panel on Climate Change. Available online: https://www.ipcc.ch/report/ar5/wg2/ (accessed on 27 August 2019). 
55. World Health Organization. Sun Protection. Available online: https://www.who.int/uv/sun_protection/en/ (accessed on 27 August 2019).

56. Wu, Y.P.; Parsons, B.G.; Mooney, R.; Aspinwall, L.G.; Cloyes, K.; Hay, J.L.; Kohlmann, W.; Grossman, D.; Leachman, S.A. Barriers and Facilitators to melanoma prevention and control behaviours among at-risk children. J. Community Health 2018, 43, 993-1001. [CrossRef] [PubMed]

57. Religi, A.; Backes, C.; Moccozet, L.; Vuilleumier, L.; Vernez, D.; Bulliard, J.-L. Body anatomical UV protection predicted by shade structures: A modelling study. Photochem. Photobiol. 2018, 94, 1289-1296. [CrossRef] [PubMed]

58. Mathee, A.; Oba, J.; Rose, A. Climate change impacts on working people (the HOTHAPS initiative): Findings of the South African pilot study. Global Health Action 2010, 3, 1-9. Available online: https: //www.tandfonline.com/doi/abs/10.3402/gha.v3i0.5612. (accessed on 3 October 2019). [CrossRef] [PubMed]

(C) 2019 by the authors. Licensee MDPI, Basel, Switzerland. This article is an open access article distributed under the terms and conditions of the Creative Commons Attribution (CC BY) license (http://creativecommons.org/licenses/by/4.0/). 